\section{Development of the Ligule in Zea Mays L.}

DURING an investigation of leaf initiation and apical organization in grasses, some particularly clear stages in the origin of the ligule were seen in young leaves of maize shoots cut longitudinally in the plane of the leaves. The development of the grass ligule has received attention from only a very limited number of workers (Bugnon 1,2, Ponzo ${ }^{3}$, Philipson ${ }^{4}$, and Neumann ${ }^{5}$ ), but all agree that it arises solely from the young epidermis. Neumann well summarizes its origin when he says "The ligule of Zea Mays arises from three horizontal rows of epidermal cells lying one over the other".

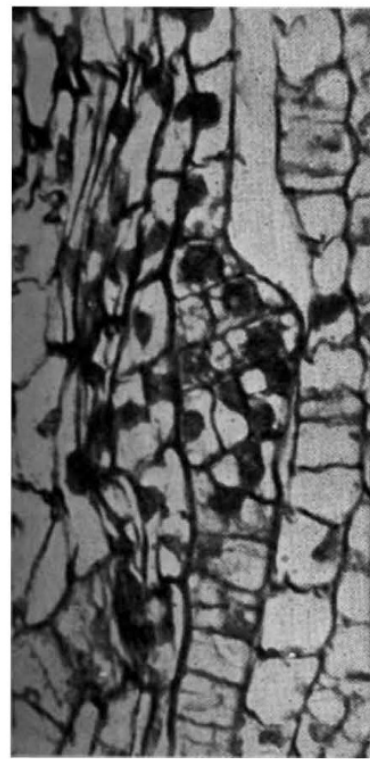

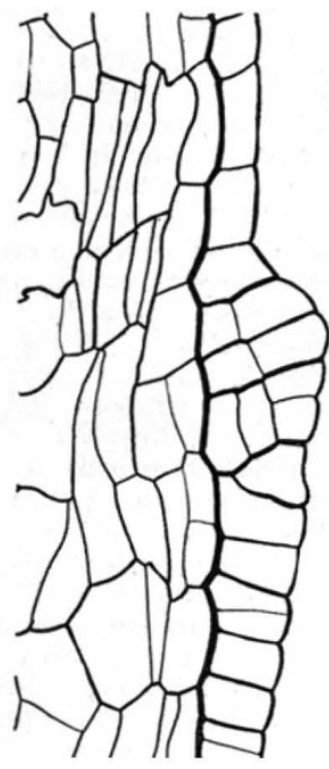

B
( $\times 780$ approx.)

The photomicrograph $A$ and the cell-wall drawing $B$ show part of a leaf, about the fifth from the apex, in a maize shoot, and illustrate the way in which the ligule is initiated by rapid periclinal divisions in a few young, rather more densely staining, epidermal cells at the union of the future lamina and sheath. Although periclinal divisions in the sub-epidermal cells accompany the divisions of the epidermal cells, the continuity of the sub-epidermal cells under the ligule and the similar continuity of the rather thicker original lower wall of the epidermal cells indicate that the tissue of the developing ligule is derived solely from the epidermis.

In all of rather more than twenty species of grasses with the simple membranous type of ligule (or reine Hautligula of Neumann) which I have examined, the origin is similar to that described for Zea, though it is often difficult to determine how many horizontal rows of cells are involved.

\section{B. C. Sharman.}

Botany Department,

The University, Leeds 2.

${ }^{2}$ Bugnon, P., Thesis, Caen (1921).

'Bugnon, P., Mém. Soc. linn. de Normandie, 26, 21 (1924).

- Ponzo, A., Nuovo Giorn. Bot. Ital., 38, 515 (1931).

- Philipson, W. R., New Phyt., 34, 310 (1935).

seumann, H., Beit. Biol. Pflanz., 25, 1 (1937).

\section{Bracken Compost}

IN two papers previously published ${ }^{1}$ attention was directed to the remarkable effects produced on the growth of young trees by the use of organic composts made from straw and other materials.

In the first instance these composts were used to promote growth of various species of pine on poor heath soils of the Bagshot type. Afterwards, they have been applied with equal success to a number of conifers other than pine, Norway and Sitka spruce, larch, Cupressus sp., etc., as also to birch and beech, and their use extended to various types of soil.

Among the materials tested recently with successful results a a basis for similar composts is bracken, from which has been prepared a compost giving highly satisfactory experimental results in tree nurseries and in the corresponding pot cultures with transported soil. In view of the desirability of eradicating bracken under certain conditions and the accumulation of cut fronds resulting from the methods recommended for that purpose, it seems of some interest and importance that experimental results proving the value of bracken compost should be put on record without further delay.

The methods for making composts successfully used in forestry experiments were described in the first of the papers cited. A standardized product was obtained in every case by careful attention to the size, packing and moisture content of the heaps, with addition of nitrogen at the rate of 1 per cent of the dry weight. The amount of nitrogen has been since reduced to $\frac{1}{2}$ per cent in certain composts without loss of quality, and a bracken compost prepared in this way is at present under comparative observation.

Various sources of nitrogen have been employed, by far the most successful being commercial 'dried blood'. The use of simple inorganic salts of nitrogen such as ammonium sulphate or ammonium phosphate has given composts of inferior quality for forestry work. Under war conditions a satisfactory organic substitute for 'dried blood' can doubtless be found. The successful use recently by Waksman ${ }^{2}$ of definite proportions of alfalfa with straw as a basis for composting is worth noting in this connexion.

Bracken compost heaps made as described develop a high temperature and show a well-marked thermophilic phase during decomposition. They break down quickly giving a sweet-smelling friable compost easy to handle. Its value for crops other than young trees requires to be tested.

A recent paper by Braid $^{3}$ on bracken eradication recommends cutting down of the fronds in June. Comparative experiments with composts made from dead fronds eut in October and from green fronds cut and dried in early July have given results slightly in favour of the green product, and these results could doubtless be extended to cuts made rather earlier in the summer if found desirable.

M. C. Rayner.

Bedford College,

University of London,

c/o The Botany School, Cambridge.

\footnotetext{
${ }^{1}$ Rayner, M. C., Forestry, 10, 1 (1936).

${ }^{2}$ Rayner, M. C., Forestry, 13, 19 (1939).

${ }^{3}$ Waksman, S. A., and Cordon, T. C., Soil Science, 47, 217 (1939).

'Braid, K. W., Scott. J. Agric., 22, 1 (1939).
} 